\title{
THE EFFECT OF JIGSAW TECHNIQUE AND STUDENTS' VOCABULARY MASTERY ON READING COMPREHENSION OF THE EIGHTH GRADE STUDENTS OF SMPN 4 SINGARAJA
}

\author{
by: \\ Ni Nengah Pariati
}

\begin{abstract}
The aim of this study was to investigate the effect of Jigsaw technique and students' vocabulary mastery on reading comprehension of the eighth-grade students of SMPN 4 Singaraja. This study was a quasi-experimental study with Posttest-Only Control Group Design by $2 \times 2$ factorial arrangement which involved a sample of 80 students. The data were collected by using vocabulary and reading comprehension test then analyzed by Two-way ANOVA and Tukey test. The result indicates that (1) there was a significant effect on reading comprehension between the students who were taught using the Jigsaw technique and those who were taught by using conventional, (2) there was a significant effect of the interaction between the implementation of teaching techniques and students' vocabulary mastery on reading comprehension, (3) there was a significant effect in reading comprehension between the students with high vocabulary mastery who were taught by using Jigsaw technique and those who were taught by using conventional technique, (4) there was a significant effect in reading comprehension between the students with low vocabulary mastery who were taught by using Jigsaw technique and those who were taught by using conventional. The result of the research showed that the Jigsaw technique was more effective for teaching reading comprehension than conventional.
\end{abstract}

Keywords: Jigsaw technique, Vocabulary mastery, Reading comprehension.

\section{INTRODUCTION}

Language is an important tool for human beings to communicate among themselves. By using language, people can talk and understand each other. They can communicate with another group of people or nations. Brown (2000:5) states that language is a system of arbitrarily conventionalized vocal, written or gestural symbols that enable members of a given community to communicate intelligibly with one another. Language is systematic and a set of arbitrary symbols. They have conventionalized meanings to which they refer.
There are many languages in the world. One of them is English. English is an international language and it is very important nowadays. Millions of people want to improve their command of English and the opportunities to learn it is provided in many different ways such as formal or informal instruction, studying abroad, the media and the internet. In Indonesia, the English language has been introduced as a foreign language in Elementary School, Junior High School, Senior High School and University level. There are four language skills taught in school including listening, speaking, 
reading and writing. From four language skills, reading is a vital life skill for everyone including for the students of any level, not only for updating students' knowledge of the latest information but also as a mean of entertainment. In other words, reading is a very important skill for students. Therefore, it must be fostered to a maximum capacity if we want our students to get the most advantage out of their education.

One of the most important factors that can influence the learning outcome is reading comprehension. Through reading, a student can get lots of knowledge or ideas to improve their grade point average. Besides, the students need comprehension skills that can help them get meaning from the reading materials. Comprehension is intentional thinking during which meaning is constructed through interaction between text and reader (Harris and Hodges, 1995).

Reading can be defined as a highly complex act (Burn,1996). It has two main components, namely a process and a product. Good readers are able to read different levels of reading selections which might contain the implementation of the high technology or useful information that might be implied in developing human development, especially education. In reading, the students sometimes get difficulty in getting meaning (word, phrase, and sentences meaning), in selecting the best meaning, and in organizing ideas or thought. Other difficulties come from disability to apply effective reading strategies that can help them to understand the printed page.
Considering the above reasons, students should have the ability to read the text well. In English as a foreign language, the emphasis of teaching and learning process tends to be on reading skills. It can be seen from the fact that most of the items of national examination consist of reading. However, the students have many problems in comprehending reading texts such as narrative, descriptive, procedure, spoof, hortatory exposition, recount, and report. It will make them will fail in their examination. Because of those reasons, the English teacher had better prepare their students to be competent in reading. The students need more time to practice reading comprehension when they want to reach a good comprehension in reading.

In the KTSP School-Based Curriculum, students are said to be competent when they have fulfilled standard competency and basic competency. Standard competency is a minimum competency that should be achieved at the end of learning and basic competency is detailed competency required for a standard competency (Depdiknas, 2006).

In SMPN 4 Singaraja, the students dominantly feel difficult to comprehend the reading. It is indicated that the students could not understand reading skill. This experience has been supported by other English teachers in this school. From 294 students of eighth grade in this school, 220 students (75\%) had high difficulties to comprehend reading text. They said that their students dominantly tended to keep silent during teaching and learning process which directly affected the low score of reading skill. It was very difficult for the students to understand the 
essential elements of reading comprehension. Students lacked the understanding to comprehend the meaning of the reading text. Students focused to learn a reading skill only for the final examination. The other English teachers also added that their students focused in learning reading comprehension only to fulfill the final examination target. There was no regulated time allocation for improving their own reading achievement. Based on an informal interview between the researcher and two English teachers in this school, students' difficulties in reading comprehension were influenced by inappropriate reading strategy applied by English teachers. From 294 students of Eighth grade, 206 students (70\%) claimed that they did not understand the reading material presented by their English teachers because of inappropriate strategies. More than that this informal interview also highlights that English teachers are still applying their conventional teaching strategy in the classroom.

Actually, to achieve basic competency and standard competency, there are many strategies that can be applied by the teacher to maximize their role in the classroom, but most of them did not try to find a variety of method and anyways to be more attractive. In terms of reading strategy, there are many strategies that can be applied to improving students' achievement in reading comprehension.

The Jigsaw technique was used to develop the skills and expertise needed to participate effectively in the group activities. It focuses on listening, speaking, co-operation, reflection, and problem- solving skills. Jigsaw is a very useful tool for trying to help students integrate knowledge and understanding from various sources and experts. The basic idea is very simple: students are divided into groups all of whom have their own research topic to study. After research, each topic group is split in such a manner that new groups have a single member from each of the old topic groups. After the new groups have been assembled each topic expert is responsible for integrating the knowledge of his/her topic-specific knowledge into the understanding of the new group he/she is in (Aronson, 1978).

Meanwhile, the relationship between reading comprehension and vocabulary knowledge is strong. Stahl (1999) reported that education research in readability, test construction, and reading comprehension found that students with more vocabulary knowledge comprehend text better than students with less vocabulary mastery.

Based on the explanation above, the researcher was used Jigsaw technique to increase the students' understanding about the text and develop teaching strategies in teaching reading comprehension. It can be applied to helping, improving and giving more enjoyable atmosphere to the students' reading comprehension. This research tried to find evidence on whether the implementation of Jigsaw technique and students' vocabulary mastery can give a significant effect on reading comprehension. The research was conducted of the eighth-grade students of SMPN 4 Singaraja in the academic year 2013/2014. 
Based on the informal interviews done to English teacher at SMPN 4 Singaraja. The problems identified were: (a) Reading Comprehension is found to be a difficult skill for the eight grade students of SMPN 4 Singaraja because the students have little interest in reading comprehension in English text, so that it becomes one of the constraints to comprehend the reading comprehension in English text, (b) Many students are not able to comprehend the English passage accurately. Due to the vocabulary mastery is limited, automatically it is so hard as the students to comprehend the English text itself, (c) Jigsaw has not been implemented. In this case, the teacher in SMPN 4 Singaraja used conventional strategy so it made the classroom was teacher-centered, and the students became passive in the classroom. The students were lazy to follow the activity that the teacher gave to the students. Therefore, the teacher should use the strategy that could be used to master the English text, especially in reading comprehension, (d) Students' vocabulary mastery needs to be increased. The students of SMPN 4 Singaraja still lack vocabulary mastery, because from the result of English task especially in reading was still bad, so that in this case the teacher must use the appropriate strategy to the students in order that they can achieve a good result in English reading comprehension.

This is a quasi-experimental study which is focused on teaching reading comprehension by using Jigsaw Technique of the eighth-grade students of SMPN 4 Singaraja in the academic year 2013/2014. This study was limited by measuring students' reading comprehension in narrative and recount text. The presence of the study is limited to four main objectives. The first, finding out whether there is a significant effect of reading comprehension between the students who are taught by using the Jigsaw technique and Conventional. The second, to find out the interaction between the implementation of teaching techniques and vocabulary mastery on the students' reading comprehension. Third, find out whether there is a significant effect in reading comprehension between the students with high vocabulary mastery who are taught by using the Jigsaw technique and those who are taught by using conventional. Fourth is to find whether there is a significant effect in reading comprehension between students with low vocabulary mastery who are taught by using the Jigsaw technique and those who are taught by using the Conventional method.

\section{DISCUSSION}

\subsection{The Concept of Reading}

Reading is one of the English skills besides speaking, listening and writing. It is the way to understand written messages. According to Dechant (1982), reading is a language process and communication that is a process which gave the opportunity to readers to interact and to communicate with different ideas. Reading always involves interaction between the writer and the reader. It is an action of a communicative process stated from the thought of the writer which is expressed by using symbols on the printed page. Without readers communication through writing on the printed page does not occur. 
Walker (1992) defines reading as an interaction between readers and their prior knowledge of the reading process. Therefore, readers' prior knowledge influences his comprehension of the text. Reading cannot be regarded as a set of mechanical skills to be learned once and for all, but rather as a complex process of making meaning from a text, for a variety of purposes and in a wide range of contexts.

Leipzig (2001) states that reading requires word recognition, comprehension, and fluency. To understand all types of information in an array of the texts, it requires not only the reading activity but also able to understand the text content, one is not able to absorb or comprehend a lot of information quickly, accurately and easily. Ability or skill of comprehending a message in the text is the goal of reading in a language instruction.

Based on the definitions above, it can be concluded that reading is the process of understanding the written text and identify the messages provided in the text depending on the reader's prior knowledge in constructing the meaning.

\subsection{Comprehension}

Dechant (1982) notes that comprehension has two general abilities: the ability to remember word meaning (word knowledge) and the ability to reason with verbal concepts, and hence with words. In this case, that comprehension is a thinking process. It is thinking through reading, which is dependent upon the learners' basic cognitive and intellectual skill, based on their background of experience (vocabularies, knowledge, concepts, and ideas) and upon language knowledge (knowledge of morphology, syntax, and grammar).

Comprehension is considered as a process in which the reader constructs meaning by interacting with text through the combination of prior knowledge and previous experience, information in the text and the reader takes in relation to the text (Pardo,2004).

\subsection{Levels of Comprehension}

Lapp \& Flood (1986) classify reading comprehension on the three levels as follows:

\section{a. Literal Comprehension}

It is a level of comprehension that needs skills in understanding the information that is directly stated in the written material. In this level, readers are expected to get the main message of the writer. Lapp \& Flood (1986) present the skills needed in this level know the meaning of words, multiple meanings might become a problem if a large number of words in the written material are unknown to the reader and comprehension suffers. That is why a good teacher, he or she should give the reading instruction first to help the learners become aware of various ways in which individual words are used.

\section{b. Inferential Comprehension}

Lapp \& Flood (1986) states that the level of comprehension refers to reading between the lines. In other words, in reading at this level, the reader is able to understand what is implied through reading. This category includes the following skills: 
1. Summarizing and organizing, both the ability to select the main idea and choose significant details.

2. Arriving a generalization, the readers need to specific instances and then decide whether the data presented are sufficient to warrant a significant conclusion.

\section{c. Critical Comprehension}

Otto (1990) explains that there are four levels that the readers need to master in reading comprehension. They are word, level, sentence level, paragraph level and reasoning level. The first level is the word level, the ability to know the meaning of the word in the sentence. The second level is sentenced level. Students able to combine the words in the sentence and understand what the whole sentences mean. The third level is the paragraph level, the ability to comprehend the words and sentences in a paragraph and also develop an understanding the meaning of the paragraph itself, in this case, the reader may identify the main idea, draw an inference or use information in the paragraph to determine cause and effect. The last level is the reasoning level, reasoning resembles the critical and creative reading, in this level the reader is able to make an evaluation and create new ideas from the text.

\subsection{Reading Comprehension}

There are many definitions of reading comprehension accepted by some experts. The most important factor that can influence the students' comprehension is word recognition.
Recognition is defined as an awareness that something perceived has been perceived before. In this text, word recognition means that the reader can determine the oral equivalent of a written or printed word. Reading comprehension is intentional thinking during which meaning is constructed through interactions between text and reader (Harris and Hodges, 1995).

$$
\text { According to Brasell (2008), }
$$
reading comprehension is the ability to take information from written text and do something with it in a way that demonstrates knowledge or understanding of that information.

Based on the explanations above, it can be concluded that reading comprehension is the process of reconstructing meaning from text. The process of reconstructing meaning is the process of transform the information that is presented and illustrated how the readers can show they understand what they read.

\subsection{The objectives of teaching reading in SMP}

Teachers must know the principles of the teaching of reading. According to Smith (2011), some principles related to reading instruction that may be helpful to teachers include the following: reading is a complex act with many factors that must be considered, reading involves construction of the meaning represented by printed symbols, there is no one correct way to teach reading, learning to read is continuing process, middle school students should be taught word recognition skills that will allow them to unlock the pronunciations and meanings of unfamiliar words 
independently, the teacher should assess each students' reading ability and use the assessment as a basis for planning instruction, reading, and the other language arts are closely interrelated, using complete literature selections in the middle school reading program is important, reading is an integral part of all content area instruction within the educational program, the middle school students need to see that reading can be an enjoyable pursuit and reading should be taught in a way that allows each student to experience success.

When we look into the objectives of teaching reading or reading competencies in the KTSP English curriculum we could say that the primary purpose of reading are: to understand nuances of meaning of, to understand steps of rhetorical development or move (generic structure of text) in the suggested written texts types: narrative, descriptive, recount, message, report, procedure, an advertisement, etc.

\subsection{Jigsaw Technique}

\subsubsection{The Definitions of Jigsaw}

Following Aronson (1978), Jigsaw is a cooperative learning strategy that enables each student of a "home" group to specialize in one aspect of a learning unit. Students meet with members from other groups who are assigned the same aspect, and after mastering the material, return to the "home" group and teach the material to their group members.

Just as in a Jigsaw puzzle, each piece- each student's part is essential for the completion and full understanding of the final product. If each student's part is essential, then each student is essential. This is what makes the Jigsaw instructional strategy so effective. Jigsaw learning allows students to be introduced to material and yet maintain a high level of personal responsibility.

The purpose of Jigsaw is to develop teamwork and cooperative learning skills for all students. In addition, it helps to develop a depth of knowledge not possible if the students were to try and learn all of the material on their own. Finally, because students are required to present their findings to the homegroup, Jigsaw learning will often disclose a student's own understanding of a concept as well as reveal any misunderstandings (Aronson,1978)

Cooperative Learning or group work method has several activities in the teaching-learning. Jigsaw is one of the activities in the cooperative learning. In cooperative learning, students cooperate with their friends to discuss the topic they study but when the students are given to study their own topic, it is the danger because the students tend only to study their own topic and the students do not want to study their friends' topic. Jigsaw is one of the activities of cooperative methods which can solve this problem. Slavin (1995:111) says that Jigsaw includes a procedure whereby students share information they have gathered with their group mates and with the other group mate in the class. Students are quizzed on all topics and the quiz scores are averaged to form team scores. So, if the team wants to be successful, the team members must not only accomplish their subtasks but also do a good job of sharing information with their teammates.

Slavin (1995:122) states that Jigsaw is one of group work or cooperative activities which are applicable in the 
teaching reading comprehension. It is one type of the simplest method of cooperative learning. This is the way to give stimulus for the students to be motivated to learn so that they will be able to read better and get the better achievement.

Teaching reading will be easier because this way asks the students to be active in the class. They will be in the team consisting of various good students and poor students. Every team consists of 5-6 students and they will study together to get better achievement in the form of individual improvement scores after taking the individual quiz. Every member of a team should be responsible for her/his own material to the member of his/her own team.

Jigsaw classroom is a Cooperative Learning technique that reduces racial conflict among school students, promotes better learning, improves students' motivation, and increases enjoyment of the learning experiences. Jigsaw is said to be able to increase students' learning since it is less threatening for many students, it increases the amount of student participation in the classroom, it reduces the need for competitiveness and it reduces the teacher's dominance in the classroom". Consequently, Jigsaw strategy can successfully reduce students' reluctance to participate in the classroom activities and help create an active learnercentered atmosphere, but even more important, the Jigsaw process encourages listening, engagement and empathy by giving each member of the group an essential part to play in the academic activity. Group members must work together as a team to accomplish a common goal, each person depends on all the others. No student can succeed completely unless everyone works well together as a team. This "cooperation by design" facilitates interaction among all students in the class, leading them to value each other as contributors to their common task (Aronson, 1978).

Studies showed that it was only under certain conditions that cooperative efforts may be expected to be more productive than competitive and individualistic efforts. Johnson \& Johnson (1999) put forward five principles for the Jigsaw strategy:

\section{a. Positive interdependence}

Each group member's efforts are required and indispensable for the group success. Each group member has to make unique contributions to the joint effort.

\section{b. Face-to-face promotive interaction}

Group members have to orally explain how to solve problems, teach one's knowledge to others, check for understanding, discuss concepts being learned and associate the present learning with the past one.

\section{c. Individual and group accountability}

The size of the group should be kept small, for the smaller the size of the group is, the greater the individual accountability may be. The teacher is expected to give an individual test to each student, randomly examine students by asking one student to present his or her group's work orally to the teacher (in the presence of the group) or to the entire class, observe each group and record the frequency with which each member contributes to the group's work, appoint one student in each group as the leader, who is responsible for asking other group members to explain the rationale 
underlying the group answers, and monitor students to teach what they have learned to the others.

\section{d. Interpersonal skills}

Social skills are a necessity for the success of Jigsaw learning in class. Social skills include leadership, decisionmaking, trust-building, communication, conflict-management skills and so on.

\section{e. Group processing}

Group members discuss how well they are achieving their goals and maintaining effective working relationships, describe what member actions are helpful and what is not, and make decisions about what behaviors to continue or change.

Jigsaw learning makes it possible for students to be introduced to material and yet bear a high level of personal responsibility. It helps develop teamwork and cooperative learning skills within all students and a depth of knowledge not possible if the students learn all of the material on them own. The students are supposed to report their own findings to the homegroup in Jigsaw learning. It quite often discloses a student's own understanding of a concept as well as reveal any misunderstandings.

\subsubsection{Steps in implementing Jigsaw technique in the classroom:}

According to Aronson (1978), the Jigsaw classroom is very simple to be used.

These are the steps of Jigsaw:

1. The students are divided into 5-6 Jigsaw groups. The groups should be diverse in terms of gender, ethnicity, race, and ability.
2. A student is appointed from each group as the leader. Initially, this person should be the most mature student in the group.

3. The lesson is divided into 5-6 segments. For example, if you want to ask the students to write a topic about the sport, you might divide the topic into the standalone topic on 1) badminton, (2) basketball, (3) swimming, (4) volleyball, (5) running.

4. Each student is assigned to learn one segment, making sure students have direct access only their segment.

5. The students are giving time to read the topic at least twice and become familiar with the topic.

6. The students are giving chance to the expert groups to discuss the main point of their segment and to rehearse the presentation they will make to their Jigsaw group.

7. The students are bringing back into their Jigsaw group.

8. Each student presents her or his segment to the group.

9. The leader of each group can manage their group and they can observe the process if the members of the group are having trouble.

10) At the end of the session, the teacher gives a quiz on the material to the students.

\subsubsection{The advantages of using Jigsaw Technique}

Aronson (1978) stated that there are some advantages of using Jigsaw technique: 
1. The students have the opportunity to teach themselves, instead of having the material presented to them. The technique fosters depth of understanding.

2. Each student has practiced it in self-teaching which is the most valuable of the entire skill teacher can help them learn.

3. The students can practice in peer teaching which requires that they understand the material at a deeper level than student typically do when simply asked to produce an exam.

4. The students become more fluent in using English.

5. Each student has a chance to contribute meaningfully to the discussion, something that is difficult to achieve in large group discussion. Each student develops an expertise and has something important to contribute.

6. Each group is discussing a followup question after the individual presentation.

Meanwhile, the other advantages of the Jigsaw technique stated in Bafile (2008) as follow:

1. The students are eager participants in the learning process and are responsible for the work and achievement while being held accountable by their peers.

2. The students have more chance to appreciate differences and share experiences through individual participation and instruction.

3. The Jigsaw classroom stimulates students' motivation and increases enjoyment of the learning experience and promotes a great deal of negotiation for meaning.

4. The Jigsaw classroom reduces students' reluctance and anxiety to participate in the classroom activities while increasing selfesteem and self-confidence.

Based on the theories above, it can be concluded that Jigsaw technique is an effective strategy to be applied in English class because it is being efficient, encouraging students to listen to each other, work as a team and have a social engagement.

\subsection{Conventional Method}

According to Scherman in Listyadewi (2008), the conventional method is categorized as a common method of teaching used by most teachers in their daily teaching. It is a kind of teacher-oriented method of teaching that is frequently conducted based on the book. There is also a limitation of variation in reading and responding to the reading. The reading activities vary on identifying difficult words, answering comprehension questions and answering the tasks in the textbook or students' worksheets.

Conventional method has the following characteristics such as the students do the task individually, the instruction is teacher-oriented class, the teacher presents the material based on the book, the instruction focuses on the result, not on the process, and it does not take much time to conduct this method because there are not many activities to do in this technique. 
Seeing the characteristics above, the method is less challenging for the students. Moreover, the students only search the answers presented in the text without connecting what they read to their real life. However, the most teacher still implements this method because it does not require much preparation except the book. In addition, this method requires less time, energy and it is easier to control the students if it is compared with group work (Listyadewi, 2008).

\subsection{Vocabulary Mastery on Reading \\ Stahl (1999) states that} vocabulary is very important for second language learners, only with sufficient vocabulary learners can effectively express their ideas both in oral and written form. Thus, they should have a good idea of how to expand their vocabulary so that they can improve their interest in learning the language. Language teachers, therefore, should possess considerable knowledge on how to manage an interesting classroom so that the learners can gain a great success in their vocabulary learning.

Further, vocabulary plays an important role in language acquisition because the mastery of vocabulary will help students to master all the language skills; speaking, listening, writing and reading. The vocabulary will make the students practice life and will strengthen the belief that English can be used to express the same ideas or feeling they express in their native language. Mehta (2009) states that vocabulary is the first and foremost important step in language acquisition. It means that in learning foreign languages, students usually learn vocabulary first before they master more complex structure.

Vocabulary mastery is not a spontaneous process which is easy to be done. The process of vocabulary mastery begins when someone is still an infant. They will master the vocabulary through the simple words by listening to the words which are uttered by someone else. It is known that English vocabulary learning cannot run successfully without English ability (English skills) because both of them are very important in English teaching and learning process. The students cannot do well in comprehension without large vocabulary, for the passages and questions involve a range of words much wider than that of daily conversation. The students should master vocabulary. It is the knowledge of the word how to use, pronounces, spell, and meaning. It is about the difficulties words in the language used to express meaning (Stahl, 1999).

Moreover, the students know that vocabulary development is essential for them to learn English, but they often do not have a clear understanding of how to go about really learning vocabulary That is why interactive teaching is of great help. There are some aspects that the students found in the vocabulary mastery namely meaning, use, spelling, and pronunciation. It can be said that the students have the difficulties in the meaning if they can describe the words on the context. The difficulties of the students use, it can be said if they are difficult to identify the use of the words then they are confused to differentiate the kinds of words which are used in the sentences. In the pronunciation, the students still have difficulty in answering this aspect. Most of 
the students were not able to identify the pronunciation of the sounds like vowel, consonant, or diphthong of the words. The last aspect that the students have the difficulties is in the spelling, they are still confused to recognize the words mentioned in the sentence.

Stanvoich (2000) suggested that the differences between young students in their word knowledge are due to the different amounts of text they are exposed to. Therefore, the number of words that the young students know can be increased by increasing the number of texts to which they are exposed. Memorization is not an effective way to gain new vocabulary. It is not possible to understand the text by simply linking the meaning of individual words. Students should learn vocabulary meanings from the text with the help of a teacher.

Based on the definitions above, vocabulary mastery can be defined as a number of words in a language which contains information about its meaning, form, and usage in the context of communication.

\subsection{Empirical Review}

Mustofa (2009) conducted a research titled The Effectiveness of Jigsaw in Teaching Speaking Viewed from Motivation. $\mathrm{He}$ has contributed an experimental research on cooperative learning specifically by using Jigsaw Technique at SMPN 2 Nganjuk. About 80 students were observed as a sample of the study. This experimental research was conducted in eight months. This study showed that there was a significant effect of teaching speaking by using the Jigsaw technique compared with the audiolingual method. Jigsaw technique was more effective than the audiolingual method.

Moreover, Meng (2010) conducted a research titled Jigsaw Cooperative Learning in English Reading. From the result of the analysis, it was found that through Jigsaw cooperative learning, the students in the experimental class benefited from the cooperative learning approach. It also fostered the interest of students' English study, arouses their motivation and improved their reading ability. Jigsaw cooperative learning embodied a learner-centered, teacher-facilitated and positive interdependent communication. So, she could be said that Jigsaw cooperative learning approach is one of the most effective ways of teaching English reading in college.

Meanwhile, Nyeneng (2011) conducted a research titled The Effect of Jigsaw Reading and Gender Difference on Students' Reading Comprehension in Grade Nine of SMPN 2 Mendoyo, Jembrana in the Academic Year of 2010/2011. From the result of the analysis, it was found that the Jigsaw strategy made better achievement in reading comprehension. It was very effective for the students to compare with the conventional method.

Another research was conducted by Dewi (2011) titled The Effect of Cooperative Reading Strategies on Students' Reading Comprehension. The study was focused to find the effect of cooperative learning method and conventional method on the achievement in reading comprehension of the students. The finding of her research showed that the experimental group outscored significantly the control group on posttest. The result of the study indicated that 
cooperative learning method was more effective for English than the conventional one.

Mujtaba (2012) conducted a research titled Teaching Vocabulary by Using Jigsaw of Seventh Grade Students of MTs Mazro'atul Huda Wonorenggo, Karanganyar, Demak in the Academic Year 2011/2012. This study was focused to investigate the effects of using Jigsaw and conventional strategy in teaching vocabulary to the students. The finding of his research showed that the Jigsaw strategy made better achievement in vocabulary and it was very effective for the students compared with the conventional.

Similar to the researches above, this present research also investigated about the effect of the Jigsaw technique, but toward other variables such as vocabulary mastery and reading comprehension. Moreover, in order to help the effectiveness of using Jigsaw technique in the learning process, in this study there were some viewing techniques which make this study different than those previous researches. Another diversity such as, first, the used of post-test only control group design in this research. Second, it focuses on investigating the effect of Jigsaw technique and vocabulary mastery (as the moderator variable) toward reading comprehension. Third, the sample of this study was also different from the previous study. The sample was the eighth-grade students of the Junior high school in SMPN 4 Singaraja.

\subsection{Theoretical Framework}

2.10.1 The significant effect of students' reading comprehension between the students who are taught by using the Jigsaw technique and those who are taught with the conventional method.

According to Slavin (1995), the Jigsaw strategy is an efficient way to learn the course material in a cooperative learning style. The Jigsaw process encourages engagement and empathy by giving each member of the group an essential part to play in the academic activity. Group members must work together as a team to accomplish a common goal; each person depends on all the others. No student can succeed completely unless everyone works well together as a team. This "cooperation by design" facilitates interaction among all students in the class, leading them to value each other as contributors to their common task.

On the other hand, the conventional teaching technique is very common, because the teachers only teach language theoretically rather than practically, therefore the teacher still use conventional strategy, the teacher just asked the students to read the text and have questions related to the text. It was not an effective technique, it just made the students will feel bored in following reading class.

Based on the explanation above, it can be predicted that the students' reading comprehension who are taught by using the Jigsaw technique and conventional are different. 
2.10.2 The significant effect of the interaction between teaching techniques and students' vocabulary mastery on reading comprehension.

Stahl (1999) states that vocabulary is a very important language aspect to master. It is a crucial component in acquiring and understand language. When we read something, it will sound good if we understand the words or vocabulary in our reading. Mastering vocabulary is the ability to get or to receive lots of words. By having and mastering vocabulary, we will know the meaning of vocabulary in the context. It can also help to avoid making mistakes in understanding a written or spoken text. The students who learn English face a classical problem dealing with English reading text, lack of vocabulary is the major one whereas, in fact, vocabulary is the most important thing in reading skill. It shows the reading and vocabulary have a close relation. We have known how important vocabulary mastery in reading activity.

Furthermore, the instructions used in teaching strategy really affect the students' reading comprehension. This learning instruction has several activities to involve the students' activity. Every step in Jigsaw stimulate the students' creativity and to build up their confidence to learn. The students' vocabulary mastery also positively affects the reading comprehension. So, it assumed that there would be an interaction effect between teaching strategy and students' vocabulary mastery.
2.10.3 The effect in reading comprehension between the students with high vocabulary mastery who are taught by using the Jigsaw technique and those who are taught by using conventional.

According to Stahl (1999), vocabulary mastery is important in reading skill. Students who have high vocabulary mastery will understand the text better and active participant. Jigsaw technique gives chance for the students to compete among groups. High vocabulary mastery students will attempt effort to achieve success. It is assumed that the students with high mastery will lead them to increase their achievement in reading comprehension.

2.10.4 The effect in reading comprehension between the students with low vocabulary mastery who are taught by using the Jigsaw technique and those who are taught by using conventional.

Students having low vocabulary mastery have several characteristics which are in contrast to the students having high mastery. They do not understand the text and passive in the activity (Stahl, 1999). By seeing their characteristics of low mastery, it is predicted that they will face some difficulties in mastering vocabulary

Based on the results of data analysis and discussions above, it can be concluded that:

1. There was a significant effect in the reading comprehension of the eighth-grade students of SMPN 4 Singaraja between the students 
who were taught using the Jigsaw technique and those who were taught by using the conventional.

2. There was an effect of the interaction between the strategies of teaching reading applied and students' vocabulary mastery on their reading comprehension of the eighth-grade students of SMPN 4 Singaraja.

3. There was a significant effect in the reading comprehension at the eighth-grade students of SMPN 4 Singaraja between the students who had high vocabulary mastery taught by using Jigsaw technique and those who were taught by using the conventional.

4. There was a significant effect in the reading comprehension at the eighth-grade students of SMPN 4 Singaraja between the students who had low vocabulary mastery taught by using Jigsaw technique and those who were taught by using the conventional way.

\section{REFERENCES}

Arikunto, S. 2006. Prosedur Penelitian Suatu Pendekatan Praktik. Jakarta: PT. Rineka Cipta.

Aronson, Elliot. 1978. The Jigsaw Classroom. Beverly Hills, CA \& London: Sage Publications.

Available at www.readingmatrix.com/articles/aj ideh/article.accessed on November 20th, 2013

Bafile, Cara, (2008). The 'Jigsaw' Approach brings Lessons to Life. Retrieved June 10, 2014, from Education-world.com:
Bolukbas, F., Keskin, F. \& Polat, M. 2011.The Effectiveness of Cooperative Learning in the Reading Comprehension Skills in Turkish as a Foreign Language. Journal of Educational Psychology Vol. 10, pp. 330-335.

Brassel, Danny. 2008. Comprehension That Work - Taking Students Beyond Ordinary Understanding to Deep Comprehension. Huntington Beach: Shell Education.

Brown, H.D. 2001. Teaching by Principles: An Interactive Approach to Language Pedagogy. New York: Addison Wesly Longman Inc.

Brown, H.D. 2000. Principles of Language Learning and Teaching (4th ed.). Englewood Cliffs NJ: Prentice Hall. Burn, C.Paul. 1996. Teaching Reading in Today's Elementary Schools. Publisher: Engage Learning

Cohen, J. 1988. Statistical Power Analysis for the Behavior Sciences (2nd ed.). Hillsdale, NJ: Lawrence Earlbaum Associates.

Dantes, Nyoman. 2007. Analisis Varians. Singaraja: Universitas Pendidikan Ganesha.

Darmadi, H. 2011. Metode Penelitian Pendidikan. Bandung: Alfabeta.

Dechant, V. Emerald. 1982. Improving the Teaching of Reading. Prentice Hall: New Jersey.

Depdiknas. 2006. Kurikulum 2006; Standar Kompetensi Mata Pelajaran Bahasa Inggris

Dewi, Moni Juliani. 2011. The Effect of Cooperative Reading Strategies on Students' Reading Comprehension. Unpublished Thesis. Singaraja: UNDIKSHA. 
Fraenkel, J.R., and Wallen, N.E. 1993. How to Design and Evaluate Research in Education. New York: McGraw-Hill, Inc.

Gall, M.D, Gall, J.P, and Borg, W.R. (2003). Education Research: An Introduction. Seventh Edition. Boston: Allyn \&Bacon.

Gregory, Robert J. 2000. Psychological Testing: History, Principles, and Applications. Boston: Allyn and Bacon.

Harris, T.L., \& Hodges, R.E. 1995. The Literacy Dictionary: The Vocabulary of Reading and Writing. Newark, DE: International Reading Association.

http://www.educationworld.com/a_curr/curr324.shtml

Johnson, D. \& Johnson, R. 1999. Learning together and alone: Cooperative, competitive and individualistic learning (5th Ed.). Boston: Allyn \& Bacon.

Kagan, S. 1994. Cooperative Learning. San Clemente: Resources for Teachers.

Keskin, Funda. (2011). The Effectiveness of Cooperative Learning On the Reading Comprehension Skills In Turkish As A Foreign Language. The Turkish Online Journal of Educational Technology volume 10 Issue 4 pp. 330- 335

Killen, Roy. 1996. Effective Teaching Strategies. Social Science Press.

Knight, Jim. 2009. Cooperative Learning Instructional Coaching. (www.instructional.coach.org.).

Lapp, D., \& Flood, J. 1986. Teaching Students to Read. NY: Macmillan Publishing Company.

Leipzig, D.H. 2001. What is Reading? Available http://wwww.readingrockets.org/a rticle/352

Listyadewi, Ni Wayan Novi. An Experimental Study on the Effect of Comprehension Achievement of the Tenth Year Students of SMAN 2 Singaraja in the Academic Year of 2007/2008. Unpublished Thesis.

Singaraja: Pasca Sarjana UNDIKSHA

Meng, Jing. 2010. Jigsaw Cooperative Learning in English Reading. Journal of Language Teaching and Research, Vol. 1, No. 4, pp. 501-504. Accessed on August, 14th 2014.

Mujtaba, Muhammad anis Rifqil. 2012. Teaching Vocabulary by using Jigsaw of Seventh Grade Students of MTs Mazro'atul Huda Wonorenggo Karanganyar, Demak in the Academic Year 2011/2012. Published Thesis at http://eprints.umk.ac.id/375.pdf retrieved on March 30th, 2012.

Murcia, Celce. 2001. Teaching English as a Foreign Language. New York: Heinle \& Heinle Ltd.

Mustofa. 2009. The Effectiveness of Jigsaw in Teaching Speaking Viewed from Motivation. Published Thesis at arifblog.com retrieved on October 15th, 2010.

Nunan, D. 1992. Research Methods in Language Learning. New York: Cambridge University Press.

Nyeneng, Luh. 2011. The Effect of Jigsaw Reading and Gender Difference on Students' Reading Comprehension in Grade Nine of SMPN 2 Mendoyo, Jembrana in the Academic Year 2010/2011. Unpublished Thesis. Singaraja: UNDIKSHA. 
Otto, Wayne. 1990. How to teach reading. Canada: Addison Wesley Publishing Company.

Pardo, Laura S. 2004. What every teacher needs to know about comprehension of the reading teacher. The Reading Teacher Vol. 58, No.3 November 2004. Page 273274. www.learner.org accessed on January 15th, 2014

Parvis, Ajideh. 2003. Schema Theory Based Pre Reading-Tasks: A Neglected Essential in the ESL Reading Class. The Reading Matrix Vol.3 No.1. in April 2003.

Rahmawati, Lela. 2012. The Effect of CIRC Strategy and Achievement Motivation toward Students Reading Comprehension of the Eighth Grade Students of SMP N 10 Mataram. Unpublished Thesis. Singaraja: UNDIKSHA.

Richards, J.C., and Rodgers, T.S. 1986. Approaches and methods in language teaching: A description and analysis. Cambridge: Cambridge University Press.

Slavin, R.E. 1995. Cooperative Learning in Teams. Journal of State of the Educational Psychologist vol. 15, pp. $93-111$.

Smith, Sandy H. 2011. Teaching Reading in Today's Middle Schools. Available at http://college.engage.com/educatio n/roe/teaching/1e/students/summa ries/ch01.html (downloaded on June 5th, 2013)

Stahl, S.A. 1999. Vocabulary Development. Newton Upper Falls, MA: Brookline Books.

Stahl, S.A., Hare, V.C., Sinatra.R.\& Gregory, J.F. 1991. Defining the Role of Prior Knowledge and Vocabulary in Reading Comprehension: The Retiring of number 41. Journal of Reading Behavior, 23 (4) pp. 487-509.

Stanovich, K.E. 2000. Progress in Understanding Reading. New York: Guilford Press.

Sugiyono, 2007. Metode Penelitian Kuantitatif. Bandung: Alfabeta.

Walker, B.J. 1992. Diagnostic Teaching of Reading: Techniques for Instruction and Assesment (Second Edition). New York: Macmillan Publishing Company.

Wiersma, W. 1986. Research Methods in Education. Massachusetts: Allyn and Bacon, Inc. 